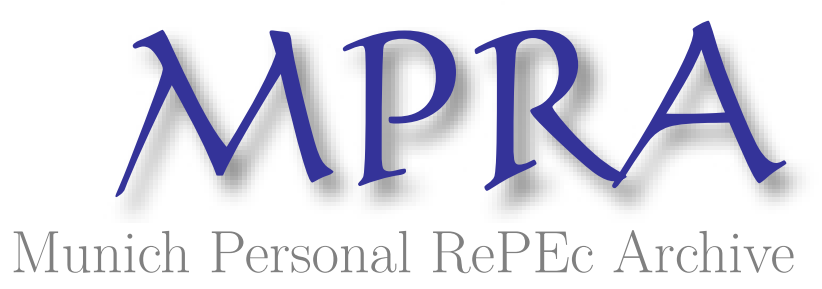

\title{
Establishing the baseline: estimating the fiscal contribution of multinational enterprises
}

CASELLA, BRUNO and BOLWIJN, RICHARD and RIGO, DAVIDE

UNCTAD, UNCTAD, Graduate Institute of Development Studies

20 November 2018

Online at https://mpra.ub.uni-muenchen.de/95190/

MPRA Paper No. 95190, posted 19 Aug 2019 10:32 UTC 


\title{
Establishing the baseline: estimating the fiscal contribution of multinational enterprises ${ }^{\dagger}$
}

\author{
Richard Bolwijn, Bruno Casella and Davide Rigo*
}

\begin{abstract}
Tax revenues from multinational enterprises (MNEs) are an important source of public finance in developing economies. The research and policy debate so far have mostly focused on the "missing" part, i.e. the government revenues lost due to the tax avoidance practices of MNEs (Bolwijn et al., 2018). In this study, we take a different, but complementary, approach, looking at the taxes and other revenues actually paid by foreign affiliates of MNEs to developing-country governments. We present two alternative methodologies to estimate foreign affiliates' fiscal contribution - the contribution method and the foreign direct investment (FDI) income method - and show that they lead to the same order of magnitude. The findings allow us to set a baseline for an informed discussion on tax avoidance by MNEs.
\end{abstract}

Keywords: multinational enterprise, fiscal contribution, BEPS, domestic revenues, developing countries

\section{Introduction: objective and scope of the analysis}

The main goal of this study is to arrive at a meaningful order of magnitude for the fiscal contribution of foreign affiliates of multinational enterprises (MNEs) to developing economies. The definition of "fiscal contribution" in this context encompasses all types of payments by foreign affiliates to host country governments, including taxes, social contributions and other revenues.

The analysis boils down to the estimation of three metrics: (a) the share of government revenues paid by foreign affiliates in total government revenues; (b) the share of government revenues paid by foreign affiliates in government revenues

\footnotetext{
† This paper draws on the technical background paper accompanying the World Investment Report 2015, chapter V "International Tax and Investment Policy Coherence", prepared under the guidance of James X. Zhan. The authors benefited from comments provided by David Bradbury, Krit Carlier, Steve Clark, Alex Cobham, Lorrain Eden, Martin Hearson, Jan Loeprick, Ruud de Mooij and Thomas Neubig. The authors are responsible for all the remaining errors.

* Richard Bolwijn and Bruno Casella are at the United Nations Conference on Trade and Development. Davide Rigo is at the Graduate Institute of International and Development Studies, Geneva. The corresponding author is Bruno Casella (bruno.casella@unctad.org). The views expressed in this article are solely those of the authors and do not necessarily represent the views of the United Nations.
} 
paid by the corporate sector; (c) the absolute amount of government revenues paid by foreign affiliates. Revenues paid by MNEs to home countries are excluded from the analysis.

The analytical effort is relevant to a number of current policy debates:

- On the financing of the Sustainable Development Goals, it helps to size the potential role of MNEs in mobilizing domestic resources for development. ${ }^{1}$

- On base erosion and profit shifting (BEPS), it helps to draw a baseline to assess the weight of the tax leakage relative to the tax contribution. The goal is to compute the fiscal contribution after profit shifting, i.e. it targets what foreign affiliates actually pay (based on what they report) after BEPS has taken place.

- To measure BEPS, it is helpful to understand the relative sizes of the categories of MNE contributions when estimating the impact of different BEPS schemes.

Despite the relevance of the research question, to our knowledge no previous studies quantify the fiscal contribution of foreign affiliates to developing economies in a systematic and comprehensive fashion. The most likely reason for this gap is the scarcity of data on taxes paid by foreign affiliates in general, and in developing economies in particular. Most MNEs do not report taxes and other financial information at the level of their foreign affiliates. ${ }^{2}$ Increasing pressure for countryby-country reporting may significantly improve information availability in the near future, but at the moment, access to relevant data on the operations and financials of foreign affiliates is still highly problematic. ${ }^{3}$

There are two main sources of information on taxes paid by foreign affiliates.

The ORBIS database from Bureau Van Dijk collects financial and business

\footnotetext{
1 The World Investment Report 2014 focuses on the role of FDI in mobilizing external sources of development financing in terms of private investments into the Sustainable Development Goals; this study complements that perspective highlighting the role of FDI in mobilizing domestic resources.

${ }^{2}$ MNEs in general do not have the obligation to report detailed business and financial information on their foreign affiliate activities. Recently, in the face of mounting pressure for tax transparency, an increasing number of MNEs are voluntarily opting to disclose tax information on their foreign operations.

${ }^{3}$ Country-by-country reporting has been a longstanding pillar of tax transparency advocacy (see, for example, the Tax Justice Network website, http://www.taxjustice.net/topics/corporate-tax/countryby-country). It makes it possible to detect distortions and misalignments in business and financial indicators of foreign affiliates, potentially indicating profit-shifting practices. In the context of the BEPS-G20 process, countries agreed on a new standard for MNEs to report their economic activities (including profits and tax payments) to the tax authority on a country-by-country basis. However this measure per se would not increase access to foreign affiliate information for the broad public, as transparency remains confined to one-to-one communication with the tax authority. Aside from the BEPS project, other ongoing transparency initiatives provide useful complementary information on the activity of MNEs in their countries of operations. A notable example is the Extractive Industry Transparency Initiative, supporting member countries (participation is on a voluntary basis) in the full disclosure of company payments and related government revenues from oil, gas and mining activities. A review of corporate transparency initiatives currently in place appears in PwC (2013).
} 
information from balance sheet and P\&L data for over 100 million companies worldwide. It is by far the largest compiler of firm-level data. More crucially, it is the only firm-level database providing comprehensive information on the ownership structure of companies; this makes it, de facto, the only option when the analytical focus is on MNEs and the operations of their foreign affiliates. However, in particular for developing regions, ORBIS suffers from severe problems of inadequate coverage and availability of financial information. ${ }^{4}$ More specifically, whereas MNE financial information is usually available at the group level with some details (especially in the case of publicly listed MNEs from developed countries), reporting of unconsolidated financials on MNE foreign affiliates is extremely poor (see, for example, the discussions in Cobham and Loretz (2014) and Tørsløv et al. (2018)).

Examples of studies using ORBIS to analyse the tax dynamics of MNEs in developing countries include Markle and Shackelford (2012, 2013), Fuest et al. (2012), and Cobham and Loretz (2014). The studies of Markle and Shackelford and Fuest et al. apply econometric techniques to a sample of firms extracted from ORBIS to analyse taxation of MNEs, either by comparing MNEs with domestic firms or by comparing MNEs with different features. More specifically, Markle and Shackelford (2012, 2013) use consolidated data from ORBIS to analyse factors influencing business groups' effective tax rates (ETRs) - taxes paid over pre-tax profit reported by ORBIS - for a sample of both developed and developing countries. Interestingly they find no evidence of a substantial difference in the ETR between domestic companies and MNEs, whereas within the group of MNEs, the locations of the subsidiaries (in financial centres versus in other countries) matter. Also, Fuest et al. (2012) explore the determinants of ETRs, based on a sample of ORBIS data focusing specifically on developing economies. Results confirm that being part of an MNE does not play a significant role in determining the ETR (unlike institutional factors such as the level of corruption).

Cobham and Loretz take a more policy-oriented perspective, where the goal is to analyse the potential impact on countries of a change in the tax system, from the current system of separate accounting to one of unitary taxation. In particular, on the basis of financial and operational data extracted from ORBIS on a sample of foreign affiliates worldwide, the paper simulates how the tax base and the tax revenues would re-partition across countries if various apportionment formulas are

\footnotetext{
${ }^{4}$ According to preliminary findings from UNCTAD, in 2015 ORBIS reported some 2,600 foreign affiliates operating in Africa. For some smaller African countries, it recorded implausibly low numbers (e.g. Burundi, 3 foreign affiliates; Benin, 8; the Congo, 15). In addition, out of the 2,600 foreign affiliates identified, more than 2,100 (more than $80 \%$ ) either do not report tax data at all or report negative or null values. For other indicators, such as turnover or employment, the coverage does not improve substantially (with data unavailable for $65 \%$ of turnover and almost $80 \%$ of employment). As a further benchmark, the Zambian Central Bank surveyed 126 active foreign affiliates in 2013, whereas an UNCTAD extraction from ORBIS returned only 36 entries.
} 
applied. Although data coverage is problematic for developing countries, the paper finds that apportioning profits according to measures of actual economic activity would result in a major redistribution of the tax base at the expense of specific jurisdictions, and in most cases towards the lower-income countries in the sample.

The second source of data on taxes paid by foreign affiliates is collected through national surveys. These foreign affiliates' statistics (FATS) include (a) statistics on the activity of affiliates operating in the reporting country (inward FATS), and (b) statistics on the activity of foreign affiliates of parents based in the reporting country (outward FATS). Since only a limited number of developed countries produce these surveys, when the object of the analysis is the activity of foreign affiliates in developing economies, the most relevant data are the outward FATS of developed countries (e.g. activity in developing economies of United States-headquartered MNEs). The coverage of FATS in terms of reporting economies depends on the financial indicators of interest. For "taxes paid" by foreign affiliates, complete FATS information is reported essentially only by the United States Bureau of Economic Analysis (BEA). ${ }^{5}$ Existing studies on MNE taxation that are based on FATS data are almost exclusively limited to foreign affiliates of United States MNEs. For a useful overview of issues related to the collection and interpretation of BEA FATS data on taxation, see Yorgason (2009). For applications of BEA tax data, see for example Clausing (2009) ${ }^{6}$ or IMF (2014). ${ }^{7}$

Unlike previous studies, the goal of the analysis in this study is to comprehensively "size a population", i.e. to measure the total amount of taxes paid by all foreign affiliates in developing economies, rather than to explore the properties of a population (for example, tax behaviours of MNEs) by generalizing from a reasonable but limited sample of firms. For this purpose, the coverage issues of the tax information in ORBIS and FATS are even more challenging. In addition, it is important to recall that both ORBIS and the BEA FATS capture only a portion of

\footnotetext{
${ }^{5}$ Bureau of Economic Analysis, International Economic Accounts (http://www.bea.gov/international/); see also Barefoot (2012). The Ministry of Economy, Trade and Industry of Japan (http://www.meti. go.jp/english/statistics/) reports some, albeit partial, data on taxation of foreign affiliates.

${ }^{6}$ Clausing (2009) leverages BEA data to analyse international profit-shifting practices of United States MNEs. The paper investigates how the profitability of foreign affiliates of United States MNEs varies with tax rate differentials. Results confirm a responsiveness of MNEs to tax rate differentials, both in the form of financial profit shifting (stronger effect) and in the form of real profit shifting (more moderate effect).

7 Similar to Cobham and Loretz (2014), IMF (2014) runs a simulation of the effect of a shift towards formula apportionment but using BEA outward statistics on United States MNEs rather than ORBIS data. Empirical evidences suggest that developed economies would systematically receive a larger portion of taxable base to the detriment of so-called conduit economies (Bermuda, Ireland, Luxembourg, the Netherlands, Singapore and Switzerland). However, for developing economies the picture is more nuanced: they would "gain" tax base only if the apportionment formula places heavy weight on employment.
} 
the total fiscal contribution by foreign affiliates. ${ }^{8} \mathrm{It}$ is not surprising that in a context where the availability of data on the P\&L-transparent component, the corporate income tax, is poor, data on other contribution items ("above the line") are barely existent. The Doing Business total tax contribution approach developed by the World Bank jointly with $\mathrm{PwC}^{9}$ circumvents the issue by computing by-country total tax corporate contributions on a pro forma basis instead of using actual data. ${ }^{10}$ This approach captures differences in the tax regimes of different countries and makes possible the assessment of the fiscal burden borne by the average firm across countries and regions, but it provides limited insights on the size of the total contribution (a function not only of the tax regime in place in a country, but also of the volume and distinctive features of the business activities performed). ${ }^{11}$

This study takes a stepwise approach that does not directly use information on taxes and other government revenues paid by foreign affiliates, subject to the major data constraints just discussed. The initial data inputs are government revenues data reported by countries; from these, the approach zooms in on overall corporate contributions (domestic and foreign), and finally on foreign affiliate contributions (figure 1). Such an approach ensures that margins of error in estimations are confined at each step along the way. Nevertheless, as the data available on foreign operations and tax payments of MNEs are limited and fragmented, the analytical approach has been heuristic, employing a variety of sources and methods to converge towards a meaningful order of magnitude of MNE contributions.

Section 2 derives a convenient representation of the average government revenue collection (size and composition of government revenues as shares of GDP) in developing countries from available government finance data (step 1 in figure 1). Section 3 shows how to allocate government revenues, according to the payer, either to business or to individuals and consumers; the objective is to size the corporate contribution (step 2). Section 4 estimates the portion of the corporate contribution borne by foreign affiliates (step 3). The calculation is performed employing two methods, leading to comparable results: the economic contribution method, presented in section 4.1 and the FDI income method, presented in

\footnotetext{
${ }^{8}$ In ORBIS this portion is limited to the corporate income tax, whereas the BEA also reports an additional category, "taxes other than income and payroll taxes"; however, it is too aggregated to provide meaningful information on the contribution side. The category is also defined as "indirect business taxes" and includes a variety of taxes, such as sales taxes, value added taxes, excises, property taxes, international trade taxes and so on. For the purpose of establishing the taxes borne by foreign affiliates, it is too aggregated as it also encompasses some taxes collected but not paid, e.g. value added taxes. ${ }^{9}$ See World Bank and PwC (2015).

${ }^{10}$ The approach uses a case scenario to measure the taxes and contribution paid by a standardized business under each country's tax regime.

${ }^{11}$ In particular the prototypical company driving the Doing Business calculation is defined as a domestic small to medium-size company, and thus potentially very different from the average foreign affiliate of a multinational group.
} 


\section{Figure 1. Overview of the methodology}

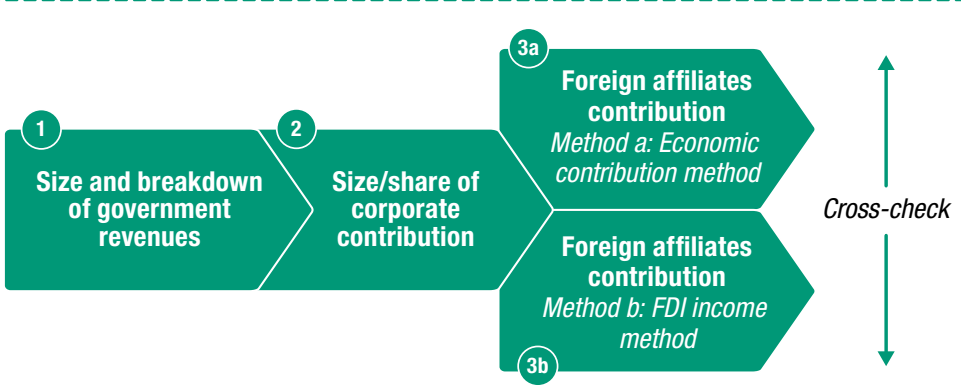

Perimeter: all revenue items (taxes, social contributions, grants, other revenues); developing economies; reference year 2012.

Source: UNCTAD.

section 4.2. The results of the three-step procedure are summarized in section 5, where they are presented both as stand-alone findings and, as baseline indicators, in relationship to UNCTAD estimations of revenue losses (from Bolwijn et al., 2018, in Part 1 of this Special Issue). Section 6 highlights some limitations of the approach and discusses ideas for future development.

\section{Size and composition of government revenues}

From available national accounts data, we derive a meaningful representation of government revenue collection in developing economies. In this context, government revenue collection refers to the average size (measured as a share of GDP) and composition (at a convenient level of granularity of the revenue components) of all revenues collected by governments. The average values for the various country groupings are then computed from national government revenue data, after weighting each country according to its GDP.

For cross-regional analysis the most relevant global sources of government revenue data are the International Monetary Fund Government Finance Statistics (IMF GFS) database and the International Centre for Tax and Development (ICTD) Government Revenue Dataset (ICTD DB). ${ }^{12}$ All these datasets face an obvious trade-off between the granularity of the revenue structure and country coverage. Such a trade-off can

\footnotetext{
${ }^{12}$ The first version of the ICTD DB was released in September 2014. For a detailed description of it, see Prichard et al. (2014).
} 
be particularly penalizing for developing economies, where information available from national governments is more limited.

The goal is to select a reference database that guarantees acceptable country coverage at a meaningful level of granularity (i.e. at a level of granularity most appropriate for the research questions).

The ICTD DB presented the most attractive balance between granularity and country coverage for developing economies. It captures data from about 120 developing countries, the largest available perimeter among government revenue databases. As explained in Prichard et al. (2014), the ICTD DB also has a number of other advantages related to consistent treatment of revenue information across countries and regions as well as a focus on natural resource revenues. Occasionally, our methodology also makes use of the IMF GFS dataset as a complementary source to extract relevant information that ICTD DB does not report. At the time of the analysis (2015), the main limit of the ICTD DB was related to timeliness: the most recent year for which it presents a consistent and rich set of revenue data was 2009 (whereas, for example, most IMF GFS data were reported up to 2015). ${ }^{13}$ However, validation procedures comparing the ICTD DB 2009 with the IMF GFS 2009 and 2012 show significant alignment in the government revenue collection for various country groupings across time. Table 1 reports the results of the comparison for developing economies. The most visible difference is the higher weight assigned by the ICTD DB to "Other revenues" at the expense of "Taxes". This is due to a systematic reallocation of the natural resource revenue items from "Taxes" to "Other revenues" performed in the ICTD DB. ${ }^{14}$

Data provided by the ICTD DB (2009) make it possible to explore government revenue collection at the global or the regional level in great detail. Such analysis reveals large variations in government revenue collection between countries and regions. A key driver for such variations is the level of income of economies (figure 2). High-income countries collect about $40 \%$ of GDP in taxes, social contributions and other revenues, low-income countries less than $20 \%$. Looking at economic groupings and regions reveals a mixed picture because of heterogeneity between countries within each region. The weighted average collection ratio of developing countries is still more than 10 percentage points lower than that of developed countries. The $30 \%$ of GDP collected in Africa, which compares favourably with the developing-country average of $27 \%$, is skewed by a few upper-middle-income

\footnotetext{
${ }^{13}$ Notice that as the other steps of the estimation process are set at 2011 or 2012 , the implicit assumption here is that on average the size and composition of government revenue collected (as a share of GDP) for developing economies has not changed significantly between 2009 and 2012. This is in line with evidence from comparison with the IMF GFS 2012 data (see table 1).

${ }^{14}$ For a more detailed discussion on the issue, see Prichard et al. (2014: 26).
} 


\begin{tabular}{lccc}
$\begin{array}{l}\text { Table 1. High-level comparison between the ICTD DB and the IMF GFS database, } \\
\text { share of GDP (Per cent) }\end{array}$ & ICTD DB 2009 & IMF/GFS 2009 & IMF/GFS 2012 \\
\hline Total taxes & $\mathbf{1 6}$ & $\mathbf{1 7}$ & $\mathbf{1 8}$ \\
Income taxes & 5 & 6 & 7 \\
Payroll & 0 & 0 & 0 \\
Property & 1 & 1 & 1 \\
Goods and services & 8 & 9 & 9 \\
International trade & 1 & 1 & 1 \\
Other taxes & 1 & 0 & 0 \\
Social contribution & $\mathbf{3}$ & $\mathbf{3}$ & $\mathbf{3}$ \\
\hline Other revenues & $\mathbf{8}$ & $\mathbf{5}$ & $\mathbf{6}$ \\
Grants & $\mathbf{0}$ & $\mathbf{0}$ & $\mathbf{0}$ \\
\hline TOTAL REVENUES & $\mathbf{2 7}$ & $\mathbf{2 6}$ & $\mathbf{2 7}$ \\
\hline
\end{tabular}

Source: UNCTAD elaboration from the ICTD Government Revenue Dataset and IMF GFS revenue data.

countries with above-average revenues (mostly due to income from natural resources) that make up for the much lower collection ratios in a large group of low-income countries. The lowest levels of revenue collection as a share of GDP are found among the least developed countries in Asia.

The breakdown in figure 3 confirms some distinctive elements of revenue composition in developing economies as compared with developed ones: (i) The substantial role of other (non-tax) revenues (which include, among others, royalties on natural resources, income on property and official development assistance or grants), particularly in Africa and LDCs (left-hand side of figure 3); (ii) the limited share of income taxes relative to other taxes such as indirect taxes and taxes on international trade (right-hand side); (iii) within income taxation, the prominence of corporate income taxes, almost twice the share of personal income taxes (as compared with one fourth in developed economies) (right-hand side of the figure). 
Figure 2. Differences in government revenue collection

Government revenues as a share of GDP, weighted averages (Per cent)

\section{By income level}

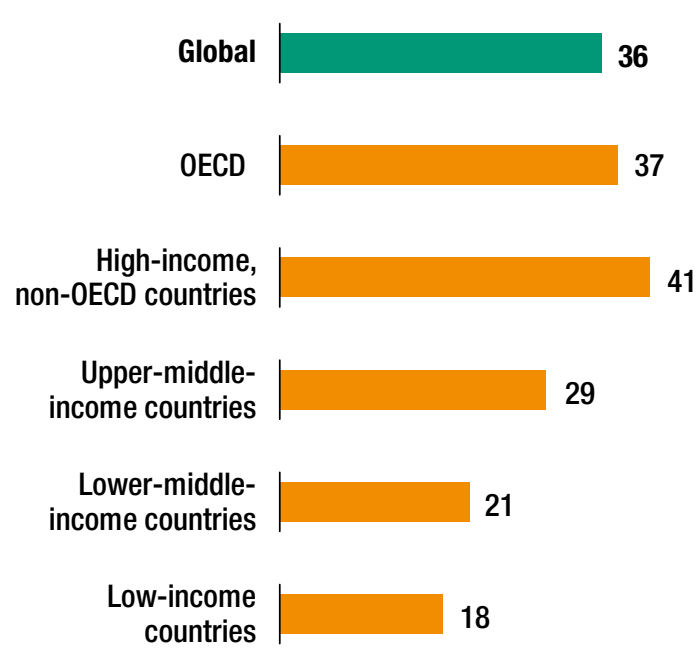

\section{By region}

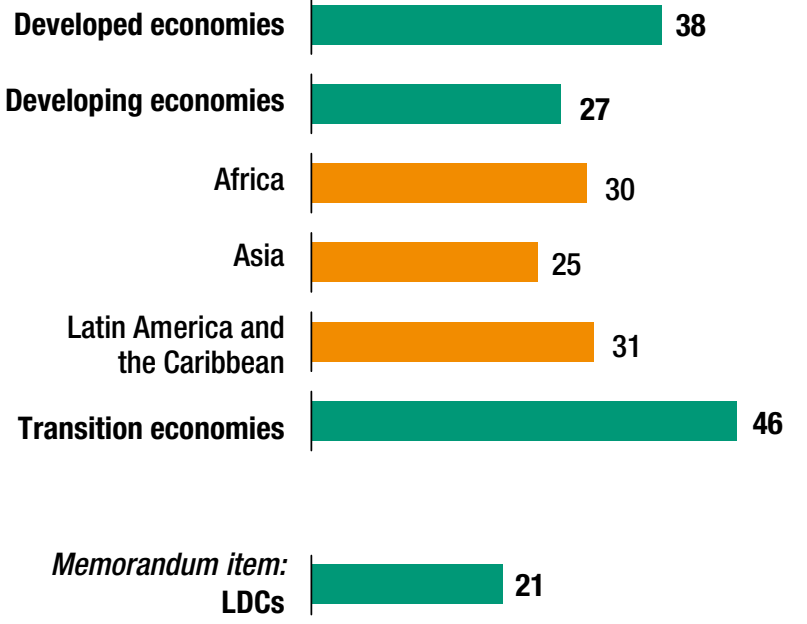


Composition of government revenues Share of total government revenues (\%)

\begin{tabular}{|c|c|c|c|}
\hline Global & 56 & 23 & 21 \\
\hline Developed economies & 56 & 25 & 19 \\
\hline Developing economies & 60 & 10 & 30 \\
\hline Africa & 53 & & 15 \\
\hline Asia & 62 & 7 & 31 \\
\hline $\begin{array}{l}\text { Latin America and } \\
\text { the Caribbean }\end{array}$ & 61 & 1 & 23 \\
\hline Transition economies & 54 & 14 & 32 \\
\hline Memorandum item: & & & \\
\hline LDCs & 51 & & 49 \\
\hline
\end{tabular}

Composition of tax component only

Share of total taxes (\%)

Income tax component

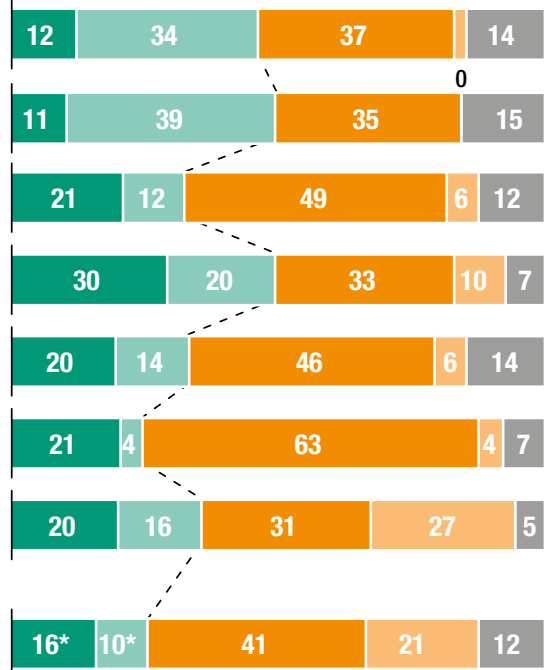

Corporate income tax

International

Personal income tax

trade

Goods and services

Source: UNCTAD analysis, based on the ICTD Government Revenue Dataset.
Note: The classification is generally based on the standard IMF GFS classification. However in the left-hand graph, the category "other revenues" includes grants (very small, at $1.5 \%$ of total government revenues in developing economies). In the right-hand graph, income taxes (corporate and personal) reflect the IMF category "taxes on income, profit and capital gains" ("payable by corporations and other enterprises" and "payable by individuals"). The residual category "others" includes taxes on payroll and workforce, taxes on property and other taxes. Data with (*) are subject to very limited coverage. 


\section{Government revenues paid by corporations}

In the process of approaching the main target (i.e. the calculation of the fiscal contribution of foreign affiliates), as an intermediate step, we estimate the share of government revenues paid by firms. For each component of government revenues derived in the previous section, our methodology arrives at an estimate for the corresponding share paid by firms ("corporate share"). It is possible to identify three main cases (figure 4).

The most straightforward case (type 1 in figure 4, column 3) arises when the estimation of the corporate share follows directly from the definition of the revenue category, so that the entire category is treated as either borne by business (corporate share at $100 \%$ ) or not borne by business (corporate share at $0 \%$ ). This includes, but is not limited to, corporate income taxes (fully borne by companies) as opposed to personal income taxes (fully borne by individuals). Other items falling in this category are international trade taxes, employers' social contribution and property income contribution (fully borne by business); and, on the other side, taxes on goods and services and employees' social contribution (not borne by business). ${ }^{15}$

In some cases (type 2 in figure 4), revenue items cannot be clearly allocated because they are too heterogeneous. They lie typically either at the lowest possible level in the government revenue classification (no further breakdown is available for their allocation) or at a level such that the more granular level exhibits too limited coverage to derive reliable statistics. Given the uncertainty about the allocation, the corporate share for these categories is set at $50 \%$. As these categories represent a

\footnotetext{
${ }^{15}$ Although allocation in this category is relatively straightforward, it does involve simplifying assumptions. In particular, two caveats should be kept in mind. First, the allocation criteria are necessarily established a priori and apply equally to all jurisdictions. As such, they reflect the formal definition and the default application of the revenue category, but they do not accommodate exceptions or nuances related to the actual implementation of the tax legislation. For example, value added tax is treated as a tax fully borne by consumers (corporate share at $0 \%$ ). This approach is valid in general, but it does not capture cases of irrecoverable value added tax, effectively borne by companies. Second, the full (100\%) allocation to the corporate component should not be interpreted too strictly; it reflects the fact that the bulk of the revenue item is paid by business. This is the case for example for the revenue item "Property income" within "Other revenues". In this approach "Property income" is fully allocated to business. However, it is a quite heterogeneous category, encompassing a number of subcategories, the most relevant being "Interest", "Dividends" and "Rent". Although a part of this is paid by individuals (e.g. public residential housing), it is reasonable to expect that in developing economies the lion's share is financed by corporations, e.g. as natural resource-related fees or rents. This is particularly true for the ICTD DB where the corporate share of "Other revenues" is even larger due to the reallocation of natural resource revenues from the category "Taxes". Similarly the assumption that taxes on "International trade" are largely paid by corporations follows from the prominent role that corporations and MNEs in particular play in international trade; UNCTAD estimates the share of trade involving MNEs at $80 \%$ of total trade (see World Investment Report 2013, p. 135).
} 
residual portion of government revenues (about 20\% of total government revenues; see figure 4, column 2), this approximation, albeit rough, does not substantially affect the aggregate estimates. The last type (type 3 in figure 4 ) arises when its subitems have been allocated; hence the allocation of the overarching category follows algebraically from the corporate shares and the mix of the subcategories.

For each relevant revenue item, figure 4 shows (a) the relative weight in the average government revenue collection of developing economies (column 2), and (b) the key elements of the estimation of the corporate contribution, i.e. the item type (column 3), the corporate share (column 4) and the resulting corporate contribution (column 5), defined here as the share paid by the corporation over total government revenues.

The application of the corporate shares identified in figure 4 to economic groups confirms higher corporate contribution in developing countries (almost half of government revenues) compared with developed countries (one third) (figure 5). The difference is caused, as noted before, by higher revenues from corporate taxes (income taxes as well as taxes on international trade and other levies) and from other revenues, especially from natural resources and property. Relative to the size of economies however the corporate contribution to government revenues is surprisingly the same across developed and developing economies, at 13\% of GDP. Higher corporate contribution in transition economies is due to relatively high income from natural resources and to the role of state-owned enterprises in the economy. 
Figure 4. Overview of the estimation of the corporate contribution for developing economies (Per cent)

Estimation of the corporate contribution

\begin{tabular}{|c|c|c|c|c|c|c|}
\hline \multirow{2}{*}{$\begin{array}{l}\text { Government revenue items } \\
\text { Total taxes }\end{array}$} & \multicolumn{2}{|c|}{$\begin{array}{l}\text { Weight } \\
\text { (share of total revenues) }\end{array}$} & \multirow{2}{*}{$\frac{\text { Item type }}{\text { type } 3}$} & \multirow{2}{*}{$\begin{array}{l}\begin{array}{l}\text { Corporate share } \\
\text { (share of the revenue item paid by business) }\end{array} \\
33\end{array}$} & \multicolumn{2}{|c|}{$\begin{array}{l}\text { Corporate contribution } \\
\text { (share of total revenues paid by business) }\end{array}$} \\
\hline & - & 61 & & & - & 20 \\
\hline Income taxes & & 20 & type 3 & 65 & & 13 \\
\hline Personal income & & 7 & type 1 & 0 & & 0 \\
\hline Corporate income & & 13 & type 1 & 100 & & 13 \\
\hline Payroll and workforce & & 0 & type 2 & 50 & & 0 \\
\hline Property & & 3 & type 2 & 50 & & 1 \\
\hline Goods and services & & 30 & type 1 & 0 & & 0 \\
\hline International trade & & 4 & type 1 & 100 & & 4 \\
\hline Other taxes & & 4 & type 2 & 50 & & 2 \\
\hline Social contributions & $\oplus$ & 10 & type 3 & 50 & + & 5 \\
\hline Employers & & $5^{*}$ & type 1 & 100 & & 5 \\
\hline Employees & & $5^{*}$ & type 1 & 0 & & 0 \\
\hline Other revenues & $\oplus$ & 29 & type 3 & 75 & + & 22 \\
\hline Property income & & $15^{*}$ & type 1 & 100 & & 15 \\
\hline Others & & $15^{\star}$ & type 2 & 50 & & 7 \\
\hline TOTAL & $\Theta$ & 100 & & & $\Theta$ & 47 \\
\hline
\end{tabular}

Source: UNCTAD analysis, based on ICTD Government Revenue Dataset and the IMF GFS.

Note: "Others" within "Other revenues" include "Sales of goods and services", "Fines, penalties and forfeits", "Voluntary transfers other than grants" and "Miscellaneous and unidentified revenues". Grants are excluded a priori from this scheme as they are irrelevant for corporate contributions.

*Split based on data from the IMF GFS dataset. Occasionally the ICTD DB does not provide the information at a level of granularity that allows a straightforward allocation, whereas the IMF GFS dataset does (at a lower level of classification). This is the case for (a) "Social Contributions" for which the ICTD DB does not provide the necessary split between employee component and employer component, and (b) "Other revenues", where no further subcomponent is reported by the ICTD DB. In these cases, the methodology leverages IMF GFS data to complement the ICTD DB and derive the required breakdown. 
Figure 5. Contribution to government revenues by firms, domestic and foreign (Per cent)

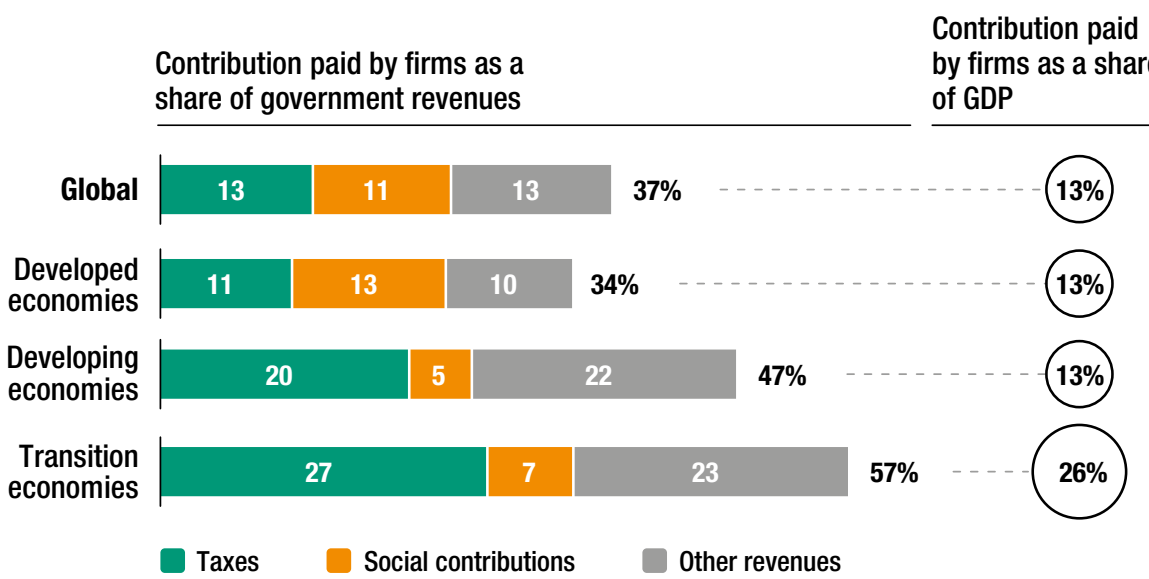

Source: UNCTAD analysis, based on the ICTD Government Revenue Dataset; IMF GFS database as complementary source.

\section{The main goal: the estimation of fiscal contributions of foreign affiliates}

The estimation of the fiscal contribution of foreign affiliates is a very challenging exercise. First, there are no directly available data on taxes paid by foreign affiliates at the country level. Second, in this setting, fiscal contribution is interpreted in a very comprehensive way, including all revenue items paid by foreign affiliates in developing countries. As already noted, in the context of developing countries, the extension to non-tax revenues (including rents and royalties on natural resources) is crucial for realistic estimation of foreign affiliates' contribution.

For robustness purposes, the estimation is carried out employing two alternative methods: (a) the economic contribution method (section 4.1), and (b) the FDI income method (section 4.2). Figure 6 summarizes the main features and the resulting estimates of the two methods.

\subsection{Approach based on the economic contribution of foreign affiliates}

It seems reasonable to assume that the portion of the corporate contribution attributable to foreign affiliates should reflect the economic value generated by those affiliates for the host economy (economic contribution). Economic value in this context must refer to reported economic value, i.e. economic value after profit shifting. 


\section{Figure 6. Overview of the estimation of the foreign affiliate contributions for developing economies}

Methods
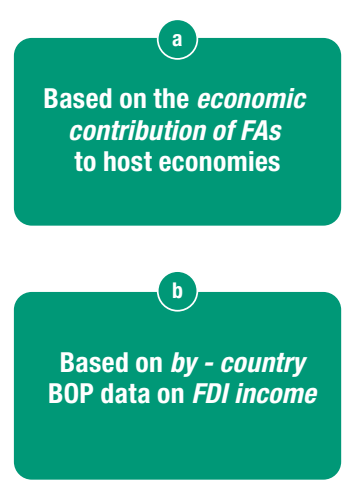

- Estimate the share of economic activity generated by multinational FAs in developing economies (economic contribution analysis).

- Align the FAs fiscal contribution to the estimated economic contribution

- Estimate the corporate income taxes paid by FAs by applying suitable effective income tax rate to the FDI income.

- Calculate the non-income component based on its estimated weight relative to the income component
FAs fiscal contribution Billion US\$
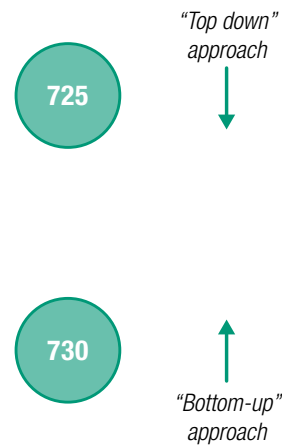

Source: UNCTAD analysis, reference year 2012.

As the corporate contribution consists of different and heterogeneous components, we employ multiple drivers of economic value creation. Each driver applies to the most appropriate components of the corporate contribution in order to best approximate the corresponding share paid by foreign affiliates.

Figure 7 illustrates the idea. Selected drivers of value creation are profits, employment, exports and value added. Each driver is naturally associated with some revenue items ${ }^{16}$ Finally, the last column reports for each driver the estimated share generated by foreign affiliates. Notice that value added (fourth bucket) is used as the default driver for the revenue categories that do not have a dedicated tailored driver. In the appendix we provide a comprehensive account of the empirical background behind the estimation of the foreign affiliate shares.

\footnotetext{
${ }^{16}$ For taxes related to labour and social contributions (second bucket), the ideal driver would be remuneration of employees, for which only very limited data are available; thus employment was selected as the second-best option. It is plausible that MNEs pay on average higher salaries than domestic companies and that therefore using employment as a driver would understate the foreign affiliate's fiscal contribution. This bias is addressed by rounding up the estimated foreign affiliate share of employment (at 6\%-9\%) to 10\%. See exact figures in the appendix. As international trade taxation (third bucket) includes both taxes on import (import duties) and taxes on exports, and the two components cannot be easily separated, the driver "exports" is used here as a generic indicator of foreign affiliates' penetration in trade.
} 


\section{Figure 7. Estimation of foreign affiliates' economic contribution in developing economies}

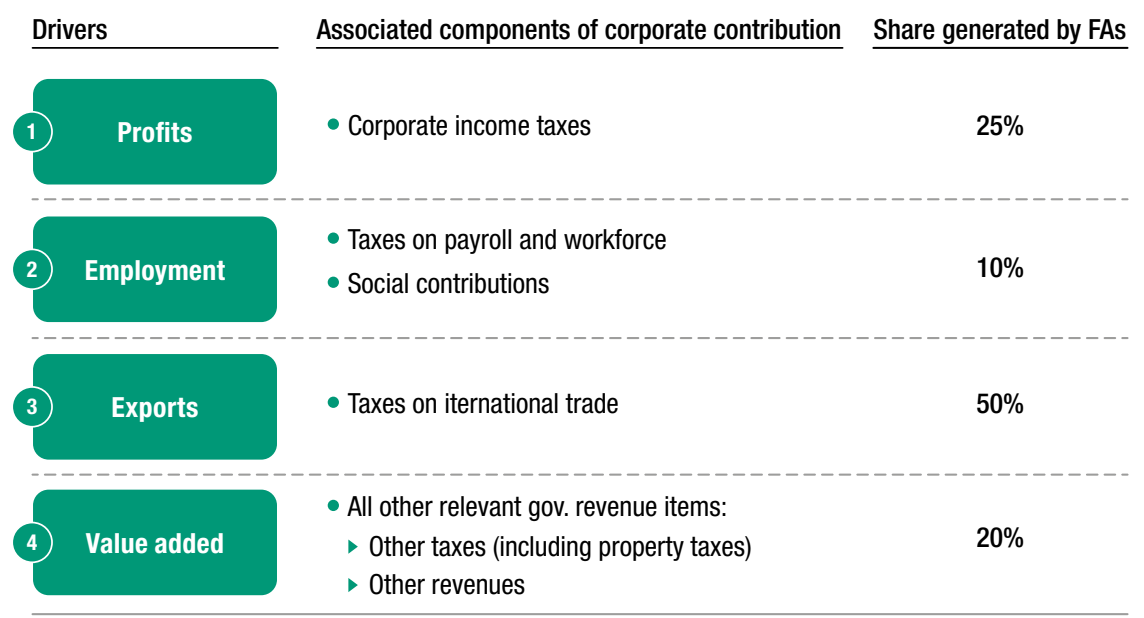

Source: UNCTAD elaboration on multiple sources.

Note: Other revenues include (non-tax) revenues from property income (mostly royalties) and the other items classified as "Other revenue" in the IMF GFS classification, namely "Sales of goods and services", "Fines, penalties and forfeits", "Voluntary transfers other than grants" and "Miscellaneous and unidentified revenues". Grants are excluded a priori from this scheme as they do not involve any corporate contribution.

Figure 8 builds on figure 4 and figure 7 and shows the whole sequence of calculations leading from revenue collection statistics to the estimate of the fiscal contribution of foreign affiliates. The estimated values presented here should be interpreted as orders of magnitude. They represent central values in range estimate intervals, due to approximations and limitations of the methodology (further explained in the last section, on limitations and areas for further research). The overall estimate of $\$ 725$ billion is the midpoint of a range with a lower bound of about $\$ 650$ billion and an upper bound of about $\$ 800$ billion. Note that this level of approximation does not have a substantial impact on the relevance of the foreign affiliates' fiscal contribution: (i) as a share of total government revenues, it falls in a range between $9 \%$ and $12 \%$; and (ii) as a share of total corporate contribution, it falls in a range of $20 \%-25 \%$. 
Figure 8. Estimation of FAs fiscal contribution to developing economies according to the economic contribution method

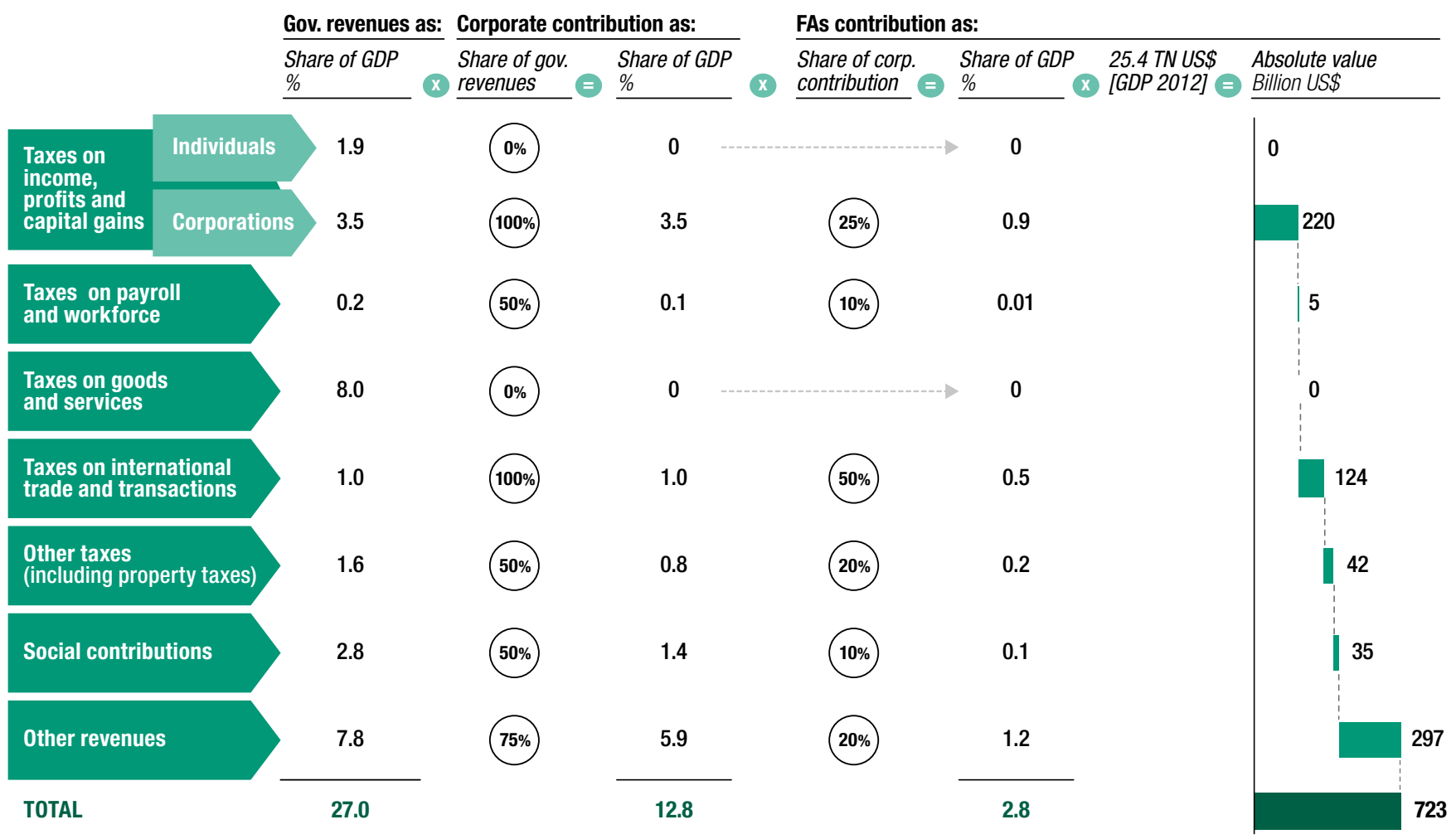

Source: UNCTAD elaboration on multiple sources, reference year 2012.

Note: Differences in totals are due to rounding. Grants are excluded a priori from this scheme as they do not involve any corporate contribution. 


\subsection{Approach based on the FDI income}

The FDI income method is driven by balance-of-payments (BoP) data on FDI income ${ }^{17}$ rather than government revenue data. It just borrows from the corporate contribution analysis of section 3 the estimation of the average mix of the corporate contribution.

Figure 9 summarizes the key elements of the approach. The FDI income method is characterized by two building blocks:

1. It leverages BoP data on FDI income (equity component) ${ }^{18}$ to estimate the corporate income taxes paid by foreign affiliates, after applying a suitable effective income tax rate.

2. It exploits the estimation of the corporate contribution performed in step 2 (section 3) to estimate the size of the non-income component relative to the income component. ${ }^{19}$

The two building blocks are independent until the last step of the calculation where the weights of the different components from (2) are applied to the corporate income taxation paid by foreign affiliates from (1) in order to estimate the total fiscal contribution of foreign affiliates.

Unlike the economic contribution method, the FDI income method proceeds from the bottom to the top: it first estimates the fiscal contribution of foreign affiliates for each developing region and then sums the results to obtain the aggregate estimate for developing economies. The total fiscal contribution, at $\$ 730$ billion, comes out as broadly consistent with the results of the economic contribution approach (at $\$ 723$ billion, figure 8, last row). The estimate of the corporate income component of the fiscal contribution is also aligned (at $\$ 200$ billion in figure 9, column 3; against $\$ 220$ billion estimated by the contribution approach, figure 8 , second row). ${ }^{20}$ From a methodological perspective, the consistency of the two estimates of the corporate income component is particularly helpful because at this stage of the

\footnotetext{
${ }^{17}$ Country data available from IMF, BoP statistics.

${ }^{18}$ The values of pre-tax FDI income are not directly retrievable from by-country BoP data. Instead, they are estimates obtained by applying to the total FDI stock of the region the average rate of return of the equity income for the reporting countries. Furthermore, as BoP-reported FDI income is by definition "after-tax" the determination of the pre-tax FDI income requires adding a (corporate income) tax component calculated using the average effective tax rates reported in column 2.

${ }^{19}$ The distribution of the corporate contribution by region is estimated following the same logic applied in figure 4 to developing economies. The only difference is that the average government revenue collection, i.e. the "starting point" (column 2 in figure 4), is calculated by region rather than for developing economies as a group.

${ }^{20}$ For the non-income component there are some moderate differences between the estimates because whereas the contribution mix resulting from the economic contribution method is specifically tailored to foreign affiliates, by construction, the contribution mix from the FDI income method inherits (from the procedure described in section 3) the contribution mix of the "average firm".
} 
Figure 9. Estimation of the foreign affiliate contribution to developing economies according to the FDI income method

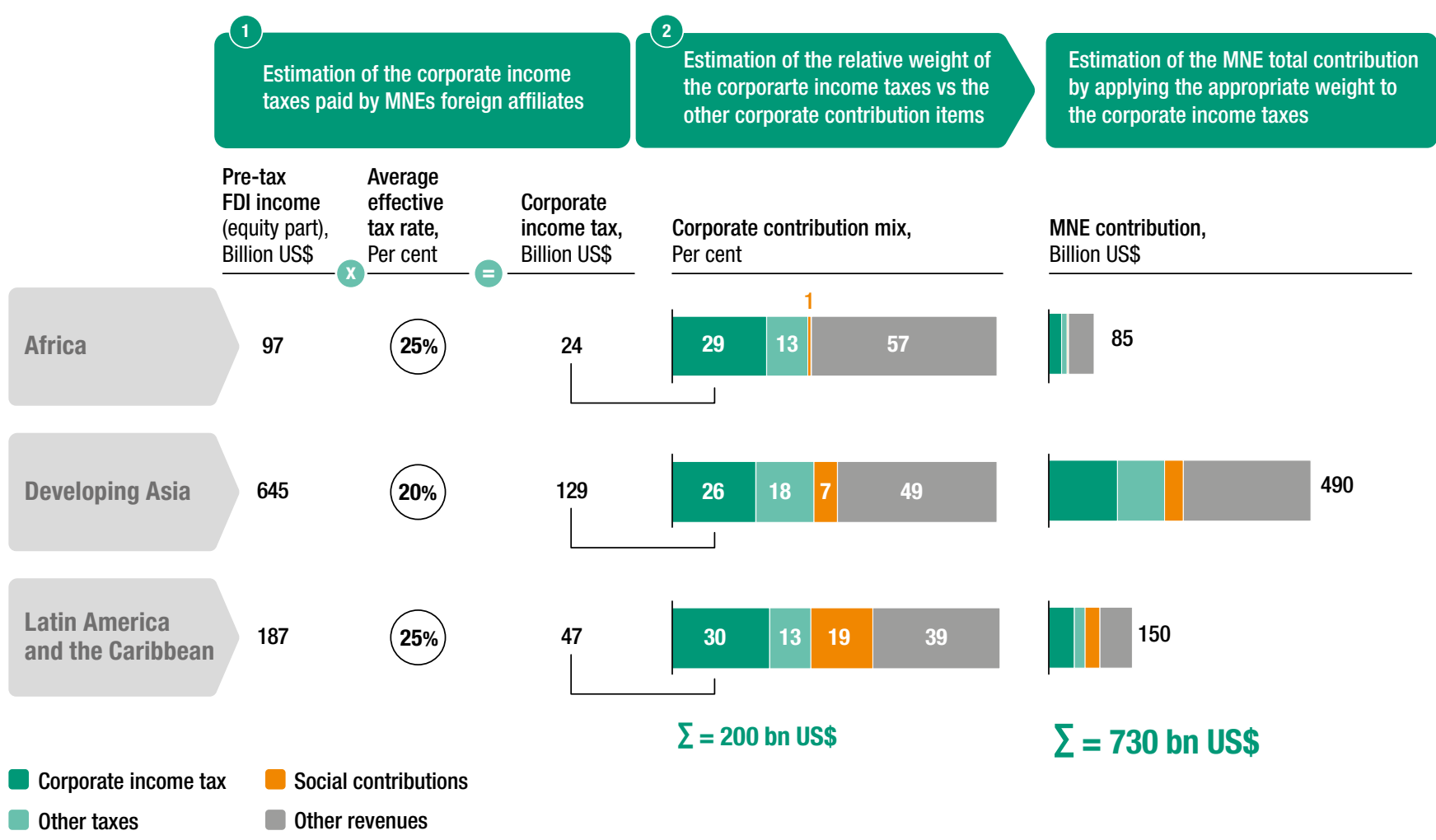


procedure the two calculations are independent, i.e. there is no overlapping of the two methodologies that may induce convergence in the results.

The two approaches should not necessarily lead to the same result. In fact, the FDI income method should in theory yield a lower estimate, given that it can take into account only the income on the foreign-owned part of directly invested enterprises, rather than the full income of foreign affiliates (although the difference should not be large, especially in developing countries). ${ }^{21}$

The value added by the FDI income method to the overall estimation process is twofold:

- Due to data constraints, the economic contribution method becomes less reliable when the perimeter of the estimation is restricted from developing economies to developing regions (Africa, Asia, Latin America and the Caribbean). In these cases, the FDI income method can provide more reliable regional estimates of the fiscal contribution of foreign affiliates, as it builds on data with better regional coverage.

- Given the fact that it is largely exogenous, the FDI income method represents a valuable validity check to test the estimation performed by the economic contribution method, which, as explained above, is imperfect.

The most challenging step of the FDI income method is to "centre" correctly the ETRs by region (figure 9, column 2). The literature review for this study did not identify any prior studies that specifically target ETRs for foreign affiliates and only a few that address developing economies. Critically, even for the same region, the literature proposes different ETRs, sometimes covering a range as large as $15 \%-30 \%$, depending on the data source, the sample of firms and countries and, above all, the methodology used for the calculation. ${ }^{22}$ Clearly, such a large variability

\footnotetext{
${ }^{21}$ Interestingly, the estimation of the corporate income component from the FDI income method, at \$200 billion, against the $\$ 220$ billion from the contribution method is consistent with the interpretation of the FDI income method as a lower bound. However, when calculating the non-income contribution items, the FDI income method applies the weights of the corporate contribution derived in step 2 rather than the weights of MNE contribution from the contribution method in step 3.a (this serves the methodological purpose of keeping the FDI income and the contribution approaches separate). The use of different weights is responsible for the convergence of the final estimates; given corporate income taxation at $\$ 200$ billion, if MNE contribution weights were applied to the FDI income method, the final estimate for MNE total contribution would be $\$ 660$ billion, a proper lower bound to the $\$ 725$ billion derived with the contribution method.

${ }^{22}$ There are two main approaches to the calculation of the ETRs: forward-looking and backwardlooking. Forward-looking metrics measure the tax burden on a pre-defined investment project. More specifically, they measure how taxes affect the cost of capital (i.e. the minimum required rate of return on an investment project). They are calculated on a stylized hypothetical investment and incorporate all the tax payments due over the lifetime of an investment, along with all the other cash flows of the investment projects. Backward-looking metrics are calculated as the plain ratio between corporate income tax payments and pre-tax income from reported accounting data. The two measures can lead to substantially different results, and this partially explains the variability observed in the literature between estimates of the effective tax rates.
} 
may have non-negligible repercussions on the final estimate. Examples of papers addressing ETRs for developing countries include Ali Abbas et al. (2012), Markle and Shackelford $(2012,2013)$ and Fuest et al. (2012). ${ }^{23}$ Ali Abbas et al. (2012) employs a forward-looking measure of the effective tax rate, ${ }^{24}$ while Markle and Shackelford (2012, 2013) and Fuest et al. (2012) resort to backward-looking approaches. The two studies of Markle and Shackelford are based on the notion of average effective tax rate (AETR), whereas that of Fuest et al. is based on the marginal effective tax rate (METR). ${ }^{25}$ As the purpose of this study is intrinsically descriptive, i.e. to derive a measure of corporate income taxation as close as possible to historical data, the backward-looking AETR approach of Markle and Shackelford, which is based on actual accounting data, seems the most appropriate. Thus, the ETRs employed in the estimation (figure 9, column 2) are substantially aligned with Markle and Shackelford $(2012,2013)$. Additional validation checks performed by UNCTAD on a sample of foreign affiliates from ORBIS also confirm these levels. The rounding of the ETRs at the 5 percentage point mark reflects the level of variability observed between the papers of Markle and Shackelford and the UNCTAD benchmark.

\section{Summary results}

The main result of the methodology described in the preceding sections is a comprehensive and multi-layered picture of the fiscal contribution of foreign affiliates: (a) covering both absolute contribution and contribution relative to the other actors in the economic system; (b) broken down by the main contribution items; and (c) including not only traditional tax items but also other revenues. Figure 10 summarizes the key numbers qualifying the MNE fiscal contribution to developing countries, calculated according to the economic contribution method (but similar numbers would result from application of the FDI income method). Of almost $\$ 7$ trillion annually received by developing countries as government revenues, just

\footnotetext{
${ }^{23}$ Also, Chen and Mintz (2013) and World Bank and PwC (2015), although they do not focus specifically on developing economies, provide effective tax rates for a number of developing countries as part of their annual ranking of countries' effective tax rates.

${ }^{24}$ Other examples of forward-looking approaches include Chen and Mintz (2013) and, to some extent, World Bank and PwC (2015).

${ }^{25}$ Although both Markle and Shackelford $(2012,2013)$ and Fuest et al. (2012) use a backward-looking formula, the approaches are different. In Markle and Shackelford, ETRs are calculated as the AETR within the sample of companies, i.e. the plain ratio between the sum of corporate income taxes paid and the sum of all the pre-tax reported profits. In Fuest et al., they are estimated through a regression model and are consequently interpreted as METRs; i.e. they represent the corporate income tax that would be paid (by the average company) on the marginal unit of profit. Resulting estimates may differ significantly as the first measure incorporates all the heterogeneity of the sample and the effect of the starting conditions, whereas the second is designed to net them off and capture the "pure" relationship between taxes and profits. Indeed, the values of the ETR estimated by Markle and Shackelford (roughly 20-25\%) turn out to be higher than the values estimated by Fuest et al. (at 10-15\%).
} 
less than half ( $\$ 3.2$ trillion) is paid by corporations. The foreign affiliates' portion of the corporate contribution corresponds to about 20\% or some $\$ 725$ billion, the first key number in our calculation. The tax component, strictly speaking, amounts to $60 \%$ of foreign affiliates' contribution ( $\$ 430$ billion), whereas the remaining part is made up of other revenues (mainly rent and royalties related to the use of natural resources). Finally, the share of foreign affiliates' taxes covered by corporate income taxation is $50 \%$, corresponding to $\$ 220$ billion, our second main figure.

In addition to information on the breakdown of government revenues, figure 10 provides a baseline to assess the relative scale of the revenue losses generated by MNE tax avoidance. A proliferation of revenue loss estimates in recent years (e.g. UNCTAD, 2015; Bolwijn et al., 2018; OECD, 2015; Crivelli et al., 2016; Tørsløv et al., 2018) has stimulated an intense discussion on the actual size of the value at stake (see, for example, the discussion in Forstater, 2015). To have an idea of the orders of magnitude, UNCTAD's estimate of revenue losses for developing countries, at some $\$ 100$ billion annually (Bolwijn et al., 2018), is comparable to the total annual amount of official development assistance (ODA) granted to developing economies (at \$115 billion in 2012, according to OECD figures).

However, it is more informative to assess the figure's magnitude relative to some meaningful baseline. To this end, it is quite common in the literature to provide revenue loss estimates as shares of GDP or total corporate income tax (e.g. Crivelli et al., 2016; OECD, 2015). GDP and corporate income tax baselines can be retrieved from national accounts with no or minimal analytical elaboration. Although they may be useful for further qualifying the scale of the revenue losses, they primarily depend on the underlying structure of the economy (e.g. the relative mix between foreign and domestic business) rather than on the tax behaviours of MNEs.

Hence, they are unable to help answer the most relevant questions: How much foreign affiliates avoid relative to what they should pay? How much foreign affiliates avoid relative to what they actually pay in total? The first question requires a quantification of corporate income tax currently paid by foreign affiliates; the second one, an estimate of all government revenues contributed by foreign affiliates, including corporate income tax, other taxes and other (non-tax) revenues. To our knowledge, this paper is the first one to pursue both directions, resulting in a comprehensive estimation of the key baseline figures, as reported in figure 10 .

On the one side, revenue losses due to profit shifting and the avoidance of income taxes ( $\$ 100$ billion) is about half of the corporate income tax actually paid (\$220 billion); or, more meaningfully, foreign affiliates manage to avoid paying one third of the corporate income taxes theoretically due to governments in developing economies. This number, more than figures in absolute value, reveals the extensive use of tax avoidance practices by MNEs. On the other side, the ratio of revenue losses to total fiscal contribution (at $14 \%$; i.e. $\$ 100$ billion relative to $\$ 725$ billion) 
Figure 10. Government revenues contributed by foreign affiliates of MNEs

Share of government revenues, developing countries, reference year 2012 (Per cent and billions of dollars)

\section{$100 \%$}

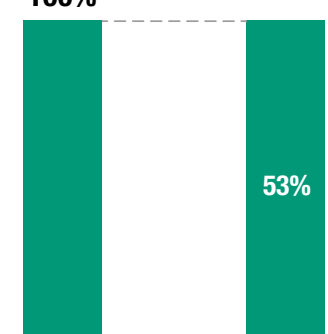

CONTRIBUTION METHOD
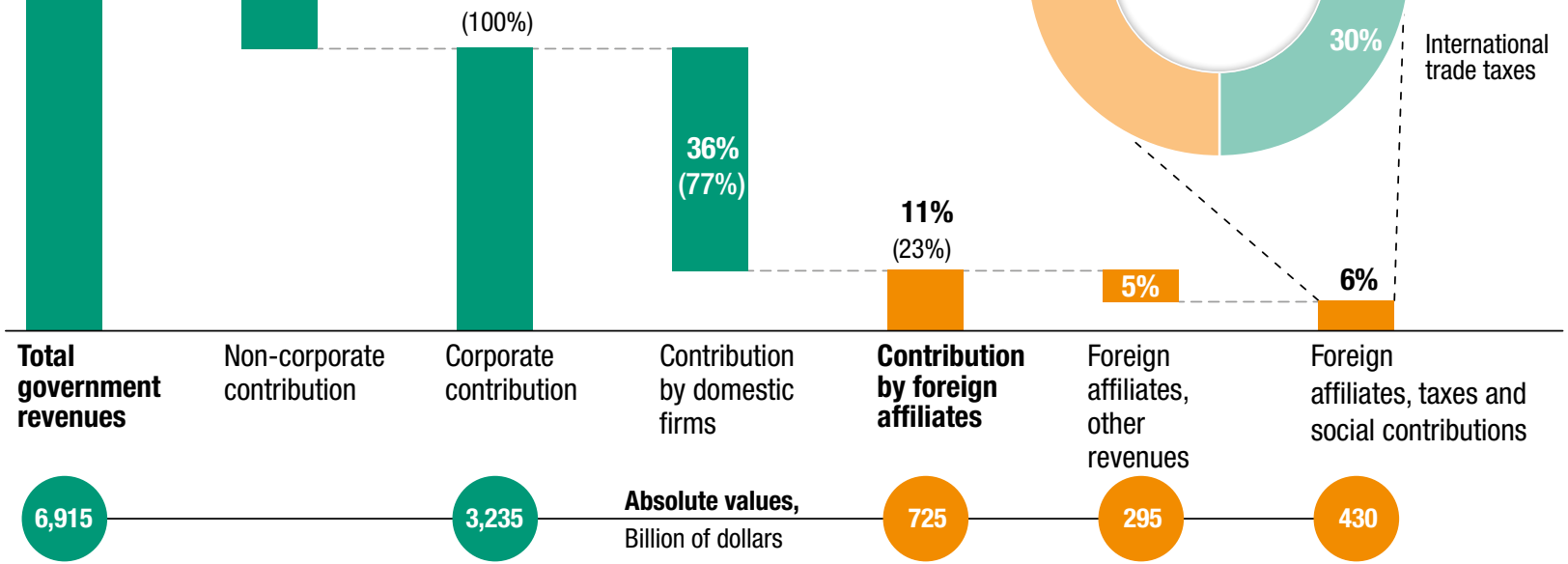

Sources: UNCTAD estimates, based on the ICTD Government Revenue Dataset, IMF GFS database, UN System of National Accounts, Eurostat, US Bureau of Economic Analysis, International Labour Organization and literature review. 
suggests that foreign affiliates significantly contribute to government collection in developing countries, even after profit shifting and revenue losses generated by tax avoidance.

Clearly, these ratios refer to the aggregate picture and can't be directly applied to individual countries, for example to size the impact of international or national tax measures to counter tax avoidance at the country-level. Impact can widely change depending on countries' economies, size and exposure to global production. Yet, on a global scale, they expose the double imperative of stopping the severe leakage of government revenues due to tax avoidance on the one side, while preserving the revenue stream generated by MNE investment on the other. The balance between there two dimensions is at the core of the policy challenges addressed by UNCTAD in its guidelines for coherent international tax and investment policies (see World Investment Report, 2015; chapter V).

\section{Limitations and areas for further research}

This study is designed to provide an order of magnitude for the fiscal contributions of foreign affiliates and to stimulate further efforts aimed at consolidating and refining the estimate. It is possible to envisage a number of analytical areas of improvement and related avenues for future investigation.

First, the most critical issue concerns the collection and exploration of operational statistics on the activity of foreign affiliates. Currently the economic contribution method relies primarily on FATS supported by a collection of heuristic and empirical evidence from a variety of other sources. Although the only consistent source of foreign affiliates data so far, FATS suffer from being driven exclusively by developed economies, either as investors (outward FATS) or as recipients (inward FATS). A more objective picture of the activity of foreign affiliates in developing economies requires complementing FATS with additional data. ORBIS is the natural and, in the short term, most feasible complement to FATS. However, analytical work needs to be done to define a methodology to select and clean ORBIS data in order to have a consistent set of foreign affiliates (ideally consistent with FATS data). In addition, robust imputation procedures are needed to complete the significant amount of missing data in developing economies. Collection of FATS data by central banks of developing countries, following some scattered examples such as those of Zambia (Bank of Zambia, 2014) or Thailand (Tattawasart, 2011), would considerably improve the information available, providing an inward FATS perspective on developing economies. Finally, public country-by-country reporting would mark a real improvement in the possibility to measure and monitor the activity of foreign affiliates in developing economies. 
Second, another key issue relates to the identification of the effective income tax rate of foreign affiliates in developing economies. As explained earlier, the literature supports a range of options, leading to quite different results. In addition, a difficult question is whether differentiated rates should be used for foreign affiliates and domestic companies. As mentioned earlier, other studies have failed to find a significant difference in rates between domestic and foreign firms. An UNCTAD preliminary analysis through ORBIS, comparing AETRs of large samples of domestic companies and foreign affiliates from different developing regions, also does not reveal any systematic gap between the two groups. Moreover, ORBIS firm-level evidence suggests ETRs for developing regions that are aligned with (or slightly above) those found in similar studies (Markle and Shackelford, 2012, 2013).

As uniform ETRs for foreign affiliates and domestic firms may appear counterintuitive, two important points should be made:

i. The fact that domestic firms and foreign affiliates are found to have similar ETRs does not preclude that MNEs, at the consolidated level, may have significantly lower ETRs due to BEPS. (ETRs are applied to the tax base that remains in foreign affiliates after profit shifting.)

ii. Many developing countries provide fiscal incentives to MNEs, which (insofar as they lower the tax rate rather than the base) would normally imply lower ETRs for foreign affiliates compared with domestic firms. Although incentives may have a significant impact at the individual country level, at the aggregate level the empirical evidence does not show any effect. Better and more disaggregated data and further research will be needed to quantify the effect of fiscal incentives.

The economic contribution method does not directly use ETRs but assumes that the ETRs of domestic companies and foreign affiliates are aligned. Consistently, in the FDI income method, the ETRs used are not "tailored" to foreign affiliates but reflect the AETRs applied to firms in the regions. The issue is sensitive and open to debate and deserves renewed empirical effort; ${ }^{26}$ its implications, beyond this study, will be relevant for the ongoing policy discussion on tax incentives and development.

Third, a number of factors may lead to potential over- or under-estimation of foreign affiliate contributions. A factor leading to potential over-estimation lies in the derivation of profits via operating surplus (see explanation in the appendix).

\footnotetext{
${ }^{26}$ For example, it would be interesting to investigate whether ORBIS may suffer from a selection bias on companies reporting tax information (excluding from its monitor exactly those companies that pay low or no taxes).
} 
Although operating surplus ratios constitute a generally accepted proxy for profit ratios in national account statistics, it cannot entirely eliminate some forms of profit shifting, in particular thin capitalization. A number of factors qualify this limitation:

- The FDI income method, which does not present this problem (it is based on reported profits of foreign affiliates), is consistent with the $25 \%$ share of foreign affiliates in total corporate profits applied in the contribution method.

- UNCTAD's preliminary firm-level analysis based on ORBIS does not reveal a systematically higher foreign affiliate share in operating surplus than in profits.

Conversely, a factor leading to potential under-estimation of the contribution, again related to the contribution method, is the treatment of "mixed income" in the calculation of the profit share from national account statistics. In particular, the contribution method presently does not strip out the non-corporate business income component from the baseline for the calculation of the foreign affiliate contribution. Removing non-corporate business income, which would be unlikely to contain any foreign affiliate contribution, would have the effect of increasing the foreign affiliate share in the remaining corporate income part, thereby increasing the foreign affiliate contribution rate. Simulation of this effect under a reasonable, conservative hypothesis of mixed income at $20 \%$ of total value added in developing economies ${ }^{27}$ yields an upper-bound estimate for the total foreign affiliate contribution of about $\$ 800$ billion. Other factors leading to potential over- or underestimation cannot be excluded a priori.

${ }^{27}$ Country data on mixed income for developing countries are scarce. However, on the basis of available data and evidence from other studies (Guerriero, 2012; Trapp, 2015), a conservative assumption is mixed income at $20 \%$ of value added. 


\section{References}

Ali Abbas, S.M., A. Klemm, S. Bedi and J. Park (2012). "A partial race to the bottom: Corporate tax developments in emerging and developing economies", IMF Working Papers, 12(28). Washington, D.C.: International Monetary Fund.

Altomonte C., T. Aquilante, G. Békés and G.I.P. Ottaviano (2013). "Internationalization and innovation of firms: evidence and policy", Economic Policy, 28(76): 663-700.

Bank of Zambia (2014). Foreign Private Investment and Investor Perceptions in Zambia. Lusaka: Bank of Zambia.

Barefoot, K.B. (2012). "U.S. multinational companies: Operations of U.S. parents and their foreign affiliates in 2010", Survey of Current Business (2012): 51-74.

Bolwijn R., B. Casella and D. Rigo (2018). "An FDI-driven approach to measuring the scale and economic impact of BEPS", Transnational Corporations 25 (2): 107-143.

Chen, D., and J. Mintz (2013). "2013 Annual global tax competitiveness ranking: corporate tax policy at a crossroads", SPP Research Papers, 6(35). Calgary: University of Calgary School of Public Policy.

Clausing, K.A. (2009). "Multinational firm tax avoidance and tax policy", National Tax Journal, 65: 703-725.

Cobham, A., and S. Loretz (2014). "International distribution of the corporate tax base: Impact of different apportionment factors under unitary taxation", ICTD Working Paper, 27, April. Brighton, United Kingdom: International Centre for Tax and Development.

Crivelli, E., R. de Mooij and M. Keen (2016). "Base erosion, profit shifting and developing countries", FinanzArchiv: Public Finance Analysis, 72(3), 268-301.

Forstater, M. (2015). "Can stopping tax dodging by multinational enterprises close the gap in development finance?", CDG Policy Paper 069. Washington, DC.

Fuest, C., G. Maffini and N. Riedel (2012). "What determines corporate tax payments in developing countries? Evidence from firm panel data". Paper presented at the XXIV conference, Società italiana di economia pubblica, Pavia, 24-25 September.

Guerriero, M. (2012). "The labour share of income around the world. Evidence from a panel dataset". Paper prepared for the 4th Economic Development International Conference of GREThA/GRES, Inequalities and Development: New Challenges, New Measurements? University of Bordeaux, France, 13-15 June.

IMF (2014). "Spillovers in international corporate taxation", IMF Policy Paper. Washington, D.C.: International Monetary Fund.

Markle, K.S., and D.A. Shackelford (2012). "Cross-country comparisons of corporate income taxes", National Tax Journal, 65(3): 493-528.

Markle, K.S., and D.A. Shackelford (2013). "The impact of headquarter and subsidiary locations on multinationals' effective tax rates”, NBER Working Paper, No. 19621. Cambridge, MA: National Bureau of Economic Research.

OECD (2015). Measuring and Monitoring BEPS, Action 11 - 2015 Report, OECD/G20 Base Erosion and Profit Shifting Project (Paris: OECD Publishing). 
Prichard, W., A. Cobham and A. Goodall (2014). "The ICTD Government Revenue Dataset”, ICTD Working Paper, 19. Brighton, United Kingdom: International Centre for Tax and Development.

PwC (2013). "Tax transparency and country-by-country reporting. An ever changing landscape", October.

Tattawasart, O. (2011). "Toward FATS and beyond: the case of Thailand". Proceedings of the IFC Conference, Initiatives to Address Data Gaps Revealed by the Financial Crisis, IFC Bulletin, 34: 488-502.

Tørsløv, T.R., L.S. Wier, and G. Zucman (2018). "The Missing Profits of Nations", NBER Working Paper No. 24701, National Bureau of Economic Research. https://doi. org/10.3386/w24701.

Trapp, K. (2015). "Measuring the labour income of developing countries. Learning from social accounting matrices", WIDER Working Paper, 2015/041. Helsinki: UNU-WIDER.

UNCTAD (1992). World Investment Report 1992: Transnational Corporations as Engines of Growth. New York and Geneva: United Nations.

UNCTAD (2012). World Investment Report 2012: Towards a New Generation of Investment Policies. New York and Geneva: United Nations.

UNCTAD (2013). World Investment Report 2013: Global Value Chains: Investment and Trade for Development. New York and Geneva: United Nations.

UNCTAD (2014). World Investment Report 2014: Investing in the SDGs: An Action Plan. New York and Geneva: United Nations.

UNCTAD (2015). World Investment Report 2015: Reforming International Investment Governance. New York and Geneva: United Nations.

World Bank and PwC (2015). "Paying Taxes 2015".

Yorgason, D.R. (2009). "Collection of data on income and other taxes in surveys of U.S. multinational enterprises". Paper prepared for the 4th Joint Session of the Working Group on International Investment Statistics and the Working Party on Globalisation of Industry Organisation for Economic Co-operation and Development, Paris, 8 October. 


\section{Appendix. Estimating the contribution profile of foreign affiliates}

There is no unique source that can provide a comprehensive picture (across the different drivers) of the economic contribution of foreign affiliates in developing economies; instead the estimation is the result of the enquiry of multiple sources that jointly form the contribution profile of foreign affiliates in developing economies (figure 7, column 3). The methodological choice to round the contribution shares at the 5 percentage point level reflects the expected degree of approximation of the estimate, as well as the ultimate objective of the analysis: to arrive at an order of magnitude estimation. ${ }^{28}$

\section{Employment (figure 7, item 2) and value added (item 4):}

- For employment and (gross) value added generated by foreign affiliates, outward FATS from the United States (BEA) and Europe (Eurostat) represent the primary sources of data. As existing outward statistics capture the activity of foreign affiliates only from a sample of investor countries (the United States and European Union (EU) countries), an up-scaling step is needed to extrapolate the worldwide data. Up-scaling is based on the shares of reporting (investor) countries in the FDI stock of developing economies.

In order to calculate the contribution share, the indicator used as the baseline for employment is the total number of employees from International Labour Organization (ILO) statistics, targeting paid employees; for the value added it is the gross value added retrievable from UN National Accounts data. The reference year is 2011, the most recent year for which Eurostat outward data were available at the time of the analysis (the BEA reported also preliminary 2012 statistics).

- The resulting estimates are the following:

- (2) Employment. Estimated share of employment generated by foreign affiliates in developing economies: (a) simple average: 9\% (of which Africa, 10\%; Asia, 12\%; Latin America, 6\%), and (b) weighted average: 6\% (of which Africa, 6\%; Asia, 6\%; Latin America, 5\%).

- (4) Value added. Estimated share of value added generated by foreign affiliates in developing economies: (a) simple average: 21\% (of which Africa, 21\%; Asia, 23\%; Latin America, 20\%), and (b) weighted average: 19\% (of which Africa, 22\%; Asia, 20\%; Latin America, 16\%).

\footnotetext{
${ }^{28}$ Approximation of the contribution shares clearly affects the final estimation. The impact of approximations remains within the overall estimation interval from $\$ 650$ billion to $\$ 800$ billion.
} 
- As a benchmark, it is also useful to consider the foreign affiliate share for developed economies, which can be retrieved using inward FATS from the BEA and Eurostat. Unlike outward statistics, these data have the advantage of providing an exhaustive picture of all foreign affiliates operating in each reporting country and, as such, they do not need up-scaling. On average the estimated foreign affiliate shares for both employment and value added do not differ significantly from the shares for developing economies (however, significant differences emerge between the EU and the United States).

- (2b) Employment - developed economies. Weighted average: 9\% (of which EU, 15\%; United States, 5\%);

- (4b) Value added - developed economies. Weighted average:13\% (of which EU, 22\%; United States, 9\%).

\section{Profits (item 1):}

- As outward FATS on profits are extremely scarce (virtually limited to the United States), an alternative argument is used, combining the preceding estimates of the foreign affiliate share for employment and value added with information retrievable from UN National Accounts statistics on the partition of the value added in developing economies. On average, the labour share of the value added generated in developing economies is about one third. ${ }^{29}$ Notice that in developed economies the picture is approximately inverted with the capital income component roughly at one third of the value added. ${ }^{30}$ In this context, given a foreign affiliate share of the labour component of the value added at $10 \%$, the corresponding share of the capital income component must be at $25 \%$

\footnotetext{
${ }^{29}$ Guerriero (2012) finds a slightly higher share, at some $40 \%$ of the value added; such a difference does not substantially affect the final estimate.

${ }^{30}$ The split between the labour and capital components of the value added proposed by national accounts statistics for developing economies should be interpreted with caution. The capital component includes the mixed income generated by self-employment; this is a hybrid item that is allocated from an accounting perspective to the capital component but that economically pertains partially also to the labour component (as remuneration of labour). As this item is particularly relevant for developing economies, the effect tends to penalize the labour share in developing economies compared with developed ones. Guerriero (2012) recalculated the labour share using more sophisticated indicators that account for the mixed-income effect and found that the labour share for developing economies would increase significantly, reaching a level almost comparable with that of developed economies (at about $60 \%-70 \%$ of value added).
} 
to align the foreign affiliate share of the value added to the estimated $20 \%$. The share in the capital income component is then taken as a proxy for the foreign affiliate share in total profits. ${ }^{31}$

- Notice that with these shares of labour and capital income, the split of value added for foreign affiliates is even more skewed towards the capital income component than for domestic companies, exceeding $80 \%$ of the value added. This is arguably due to higher productivity of labour in foreign affiliates, ${ }^{32}$ as well as higher penetration in capital-intensive sectors.

- As for employment and value added, foreign affiliate shares for developed economies that are based on inward FATS present values close to the estimated shares for developing economies. In particular, the estimation from Eurostat inward FATS on gross operating surplus for a number of European countries gives a weighted foreign affiliate share of $25 \%$ (30\% as a simple average).

\section{Exports (item 3):}

- Exports are also not systematically reported by FATS statistics. In addition, as exports are not a standard item of the balance sheet, coverage is also very limited in firm-level databases such as ORBIS. Nevertheless, leveraging insights from UNCTAD's previous analyses, especially on global value chains (see WIR13), and integrating them with the scattered evidence available from individual countries, a conservative estimate of the foreign affiliate share is proposed, at about $50 \%$ of total exports from developing economies.

- The World Investment Report 2013 (see figure IV.8) estimates that on average foreign affiliates generate some $35 \%-45 \%$ of the (domestic) value added incorporated in developing countries' exports. The bulk of this value added is arguably part of foreign affiliates' exports, so that the range represents a lower bound for the share of exports generated by foreign affiliates. ${ }^{33}$

\footnotetext{
${ }^{31}$ This step entails some assumptions. In national accounts statistics, a generally accepted proxy of (pretax) profits is the net operating surplus. Although the net operating surplus is the largest constituent of the capital income component of the value added, it is not the only one; depreciation and taxes and other subsidies also enter into the computation. The implicit assumptions here are that the share of foreign affiliates (at 25\%) is the same for all the elements of the capital income component of the value added and that the share of foreign affiliates in profits is the same as in operating surplus. This caveat was discussed in the section on limitations and areas for further research.

${ }^{32}$ Using firm-level data from a sample of European countries, Altomonte et al. (2013) show that the productivity of labour is higher for more internationalised firms. In developing economies this effect is expected to be even more pronounced.

${ }^{33}$ The component to add on top of the $35 \%-45 \%$ share to obtain the foreign affiliate share in exports is the part of the domestic value added incorporated into foreign affiliate exports that is generated by domestic companies.
} 
- The World Investment Report 2013 (figure IV.14) also states that about 80\% of global trade involves MNEs, of which one third is intra-firm trade, one third arm's length trade and the remaining third non-equity-mode-generated trade. It is reasonable to assume that the MNE share in trade in developing economies would be at least equally high and that the contribution of foreign affiliate exports to intra-firm trade and arm's length trade would represent a major component of that share.

- A number of studies at the level of individual countries also confirm the prominent role of foreign affiliates in trade.

- Developing economies. Available information at the country level suggests a share of exports generated by foreign affiliates in developing economies equal to or higher than $50 \%$ of total exports.

- In China in 2012, foreign affiliates accounted for $50 \%$ of exports and $48 \%$ of imports (see World Investment Report 2013, box IV.3).

- In smaller countries the share may be significantly higher. From inward FATS data collected by Thailand's national bank, in 2007 the share of exports generated by foreign affiliates was $75 \%$, and the share of imports was $72 \%$ (see Tattawasart, 2011).

- Similarly, the Bank of Zambia estimates the share of exports generated by foreign affiliates at $81.6 \%$ of total exports in 2013 (55.1\% of imports) (see Bank of Zambia (2014)).

- Developed economies. For benchmark purposes it is useful to recall also the available data on the foreign affiliate share of exports for developed economies (expected to be substantially lower than developing economies).

- From World Investment Report 2013, box IV.3, the foreign affiliates in the United States accounted in 2010 for 20\% of exports; in France they accounted for $34 \%$.

- The OECD also reports some scattered statistics on foreign affiliates' exports. In 2007 the foreign affiliate share in exports from European countries varied considerably: from $22 \%$ in Italy to over $50 \%$ in Poland and Estonia.

- Historical perspective. From a more historical, but still meaningful, perspective, the World Investment Report 1992 provides estimates of foreign affiliate shares in exports for a number of developing economies, documenting that, already in the late 1980s, those shares in many Asian and Latin American countries were over $25 \%-30 \%$, with some peaks of $40 \%-50 \%$. 